Athens Journal of History - Volume 8, Issue 1, January 2022 - Pages 9-30

\title{
Wars and Foreign Interventions in Greece in the 1820s
}

\author{
By Gregory T. Papanikos*
}

\begin{abstract}
In Greece, the 1820s is a well-remembered decade. Many things happened which future Greek generations can study and learn. In the beginning of the decade (1821), some Greeks rebelled against the Ottomans, but, parallel with this War of Independence, they, as did so many times in their heroic past, started fighting between themselves (18231825). The Olympians intervened, as in Homer's masterpieces, and "independence" came as a result of a direct foreign (divine) intervention by Britain (Poseidon), France (Athena) and Russia (Hera). This began first in the battlefields in 1827, and then at the negotiation table in 1832. This paper looks at the reasons of all of these three types of events (the Greek War of Independence, its civil wars and the foreign interventions), as well as their results. The reasons are traced by applying the rule: "follow the money." Of course, the obvious result was the official creation of an "independent" Greek state. However, other concurrent events have had long-lasting effects on the Greek political and military developments, which lasted until the end of the third quarter of the $20^{\text {th }}$ century. These developments are only briefly discussed in this paper.
\end{abstract}

\section{Introduction}

The year 2021 marked the bicentennial of the beginning of the Greek War of Independence, which lasted almost for a decade. At the end of the War, a new Greek state was established by the London Conference and the Treaty of Constantinople; both taken place in 1832. This period of eleven years was marked by (a) a Greek revolt against the Ottoman Empire which erupted in February of 1821; (b) two civil wars (1823-1825) which had taken place in the midst of fights with Ottomans; and (c) a war between the Ottomans and the three European powers (Britain, France and Russia) which culminated with the navy battle of Navarino in 1827, and some skirmishes between French and Ottoman armies in 1828. After these events, the Ottomans understood, the hard way, that Britain, France and Russia meant business; especially international business. In those years, when international businesses were involved, the British excelled and Greece was not an exception as I shall explain later in this paper.

The purpose of this paper is to answer the following questions: (a) what were the reason(s) of the Greek revolt against the Ottoman Empire in 1821? (b) how can the two civil wars be explained at the peak of this War of Independence? (c) what was the role of the concurrent world's political, social and cultural environment, especially in Europe, which might explain the interventions (economic, political

"President, Athens Institute for Education and Research, Greece; Honorary Professor of Economics, University of Sterling, UK; and Professor, MLC Ljubljana, Slovenia. 
and military) of Britain, France and Russia? (d) in particular, how did the intellectual movements of enlightenment and romanticism affect the course of the war events and the eventual establishment of the Greek state? The events of the 1820s have had many consequences. For example, as shall be seen, the Greek War of Independence is considered as the first example of a foreign intervention which was the outcome of public opinion pressures on national governments. This might be true, but "money had talked" before that.

This paper's structure is as follows. The next section summarizes the relevant theoretical literature which is pertinent to the issues addressed in this paper. Why do a group of people revolt? How can internal conflicts within the same group, and especially a civil war, be explained? On top of these, how can foreign intervention be explained? Selective theoretical works on these issues are presented in the next section emphasizing the economic aspects of all of these events. This background theoretical literature is then applied to the three events of Greece in the 1820s. Two descriptive models are developed to motivate the discussions on the reasons of the revolt and the civil wars (first model), as well the foreign intervention (second model). The last section concludes with a discussion on the long-term effects on Greek international and domestic political developments well into the $21^{\text {st }}$ century.

\section{An Integrated Theoretical Approach: A Selective Literature Review}

This section selects to examine a small number of papers which look at the theoretical aspects of revolutions, civil wars and foreign interventions. This literature serves well the sole purpose of this study mentioned above. However, there is a selection bias towards papers which emphasize the economic aspects. In other words, a claim is made that all three events can be explained by looking at economic and business dimensions which are considered here as the main causes of the Greek revolt, the two civil wars and the foreign interventions.

It is difficult to distinguish between a general war and a civil war. ${ }^{1}$ What was the Greek War of Independence? It was a war that took place within the boundaries of a sovereign state, i.e., the Ottoman Empire. Greeks were part of the empire, and in this way, it was an internal affair. Was their revolt a war against a foreign power, or a civil war? Eckstein used other terminology and called these wars internal wars. ${ }^{2}$ One of the objectives of an internal war might be the change of the constitution, and therefore the socioeconomic status. Eckstein used other terms as well, such as revolution, revolt, insurrection, rebellion, uprising, guerilla

1. I reviewed this literature on wars and civil war in my book G. T. Papanikos, $O$

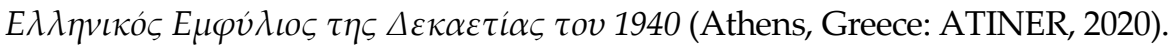

2. H. Eckstein, "On the Etiology of Internal Wars," History and Theory 4, no. 2 (1965): 1331-1363. 
warfare, mutiny, coup d' etat, and terrorism. ${ }^{3}$ The latter term was used by the Sultan of the Ottoman Empire to describe the Greeks who participated in what the Greeks called a War of Independence. As it turned out, the most important countries in the world at the time accepted the Greek interpretation of the conflict.

Economists usually assume that wars are exogenous; presumably to be explained by other social sciences. Most economists would take them as given and proceed with an analysis of their consequences - like a natural disaster such as a pandemic, an earthquake, a flood, a fire, etc. However, there do exist few papers which emphasize the economic explanations of revolutions and wars. For example, Roemer has developed a theoretical economic model in which wars (revolutions, civil conflicts and foreign interventions) are treated as an allocation (redistribution) problem between two groups of people: one group supports the current regime (e.g., the Ottoman Empire) and the other group wants to overthrow it (e.g., the Greek rebels). ${ }^{4}$ The latter group desires to overthrow the former in order to improve its income and wealth distribution while the former fights hard not to lose the benefits which arise from the existing distribution. Thus, both groups fight to increase (maintain) their welfare or to improve (maintain) their living conditions. ${ }^{5}$ Rationality is impended in the model by assuming that there is an optimal distribution advocated by the two conflicting groups (i.e., you will be better off under our rule), a punishment announced by the dominant group (e.g., a massacre of your entire family and confiscation of your property) and a possible war coalition of both groups with foreign powers (e.g., Austria, Britain, France, Russia, etc.).

This description of the model may explain the Greek revolution against the Ottoman Empire. The latter was developing a rational strategy which minimized the probability of a revolution. This approach included both punishments if people participated in the revolution and/or rewards if they did not join. In addition, international relations were promoted to form coalitions with other powers to suppress the outbreak of the revolution, e.g., Austria and Russia. As it turned out, the Ottoman Empire failed miserably on this conclusive endeavor. On

3. Ibid.

4. J. E. Roemer, “Rationalizing Revolutionary Ideology,” Econometrica 53, no. 1 (1985): 85-108.

5. A careful reader would point out that all wars can be analyzed as economic phenomena. The Greek War of Independence can be considered as the demand for a commodity, namely national freedom. Why did they want freedom? A part to this answer is economic freedom, i.e., the freedom to produce, consume, invest, and in general, doing business within an institutional framework which applies equally to all subjects. Unequal distribution of freedoms leads to unequal distribution of income and wealth. In many cases the latter dominates any other type of freedom. For example, a nationality within an empire may not enjoy political freedom as the dominant nationality, but they enjoy as much freedom as anybody else to do business. Singapore is a good modern example. Of course, free business means free movement. 
the other hand, the opposing group, who wants to overthrow the regime, (a) punished those who did not participate, (b) rewarded those who participated with the promise of spoils and (c) built up international coalitions to support them to achieve their endeavors, e.g., Britain. The Greek rebels whom were assisted by a favorable world public opinion received the decisive support of the Great Powers.

Roemer's model abstracts from any ideological influences by assuming that both groups are non-ideological. Thus, the whole discussion of the influence of enlightenment, romanticism and religion (all being weighed as ideological variables) is superfluous in the context of this theoretical model. What are the consequences of this model? Roemer comes up with twelve results which emerge from his theoretical model. ${ }^{6}$ Here, I discuss only those which relate to the context of this study. First and foremost, not mentioned explicitly by Roemer, there is always a non-negative probability of revolt. In his model there are three groups of stakeholders: poor people (e.g., most Greeks, mainly peasants, under the Ottoman yoke), a middle stratum (e.g., Greeks who had special privileges under the Ottoman rule such as the well-known Phanariotes and local Demogerontes) and the rich chieftains (e.g., Ottomans of Turkish origin). ${ }^{7}$ The latter group was benefited primarily from what economists would call today "economic rents" provided by Ottoman authorities. According to this model, the poor will always participate in the revolutionary coalition, the middle class will be in-and-out, depending on the circumstances, and the rich will always be outside the revolutionary coalition. If the probability of revolution is high and the situation is highly polarized, then the middle class disappears and joins the ranks of the poor. The severity of penalties of participating in a revolution is a monotone function of wealth; the higher the wealth, the more severe the penalties could be. In other words, poor people have nothing to lose. The results of the revolt are highly unstable.

Esteban et al. make the same arguments as Roemer by emphasizing the economic motivations of results, but find its economic "... expression through the cleavages generated by religion, ethnicity, or national origins. It could be further exacerbated by hatreds and resentments-perhaps primordial, perhaps owing to a history of violence - that are attached to the markers themselves." ${ }^{8}$ In earlier papers, Esteban and Ray, and Esteban and Debraj developed a theoretical model

6. Roemer, “Rationalizing Revolutionary Ideology,” 1985, 106-107.

7. According to Finlay (1861, p. 21) "The Greeks were allowed a considerable share authority in the executive administration of the Ottoman government."

8. J. Esteban, L. Mayoral and D. Ray, "Ethnicity and Conflict: An Empirical Study," American Economic Review 102, no. 4 (2012): 1311. 
where income inequality (or land ownership) is proxied by ethnicity because the former is difficult to observe. ${ }^{9}$

An interesting idea was proposed by Grossman which might be considered as a theoretical explanation of what went on before and during the 1820s in Greece. ${ }^{10}$ Grossman's argument is that all wars can be explained as a rivalry between two kleptocratic leaders (or groups). This analytical framework can explain the organization of some Greeks into smaller groups of gangs headed by a kleptocratic leader who were after the Ottoman kleptocrats. Once the Ottomans were beaten on the battlefields in the first and second year of the revolution, then the kleptocratic Greek gangs started fighting between themselves over the spoils of the Ottomans until a great power, Britain (a kleptocrat of a different scale), stepped in and stabilized the situation. The British interference in the Greek War of Independence started earlier as an economic interference, in 1824, then continued as a military one in 1827 , and ended at the negotiating table with the Ottoman and Greek authorities in 1832. After 1832 the British interference in the Greek internal and external political and military affairs continued until 1947 when this "property right" was transferred to the new superpower of USA. One may think that this ended in 1981 when Greece was accepted as a full member of the European Economic Community (European Union).

In another significant paper, Acemoglu and Wolitzky examined the "conflict spirals" defined as the recurrence of the same events due to mistrust. ${ }^{11}$ This may also be interpreted that generations after generations do not learn from previous generations' mistakes. At the end, all of these conflict spirals wear out. This model explains how two opposite groups come to an agreement; it involves foreign interference. Thus, an explanation is needed to describe foreign involvement into an "internal conflict."

How can foreign intervention be explained? According to Aidt et al., "In an interconnected world, where one nation's fortunes or misfortunes influence those of others, economic and political interests inevitably reach beyond national borders." 12 This is as old as the written history itself. Herodotus, the father of history, was the first to demonstrate this with the wars between some Greek citystates and the Persian Empire. But it was left to Thucydides' masterpiece of the

9. J. Esteban and D. Ray, "Conflict and Distribution," Journal of Economic Theory 87, no. 2 (1999): 379-415; Esteban and R. Debraj, "Linking Conflict to Inequality and Polarization," American Economic Review 101, no. 4 (2011): 1345-1374.

10. H. I. Grossman, "Kleptocracy and Revolutions," Oxford Economic Papers 51, no. 2 (1999): 267-283; Grossman, "A General Equilibrium Model of Insurrections," The American Economic Review 81, no. 4 (1991): 912-921.

11. D. Acemoglu and A. Wolitzky, "Cycles of Conflict: An Economic model," American Economic Review 104, no. 4 (2014): 1350-1367.

12. T. S. Aidt, F. Albornoz and E. Hauk, "Foreign Influence and Domestic Policy," Journal of Economic Literature 59, no. 2 (2021): 426. 
Peloponnesian War to manifest, in an unequivocally manner, how a state's fortune can be affected by direct or indirect foreign interventions.

Aidt et al., define foreign intervention or influence as an interaction between a foreign power and another one which the former wants to influence. ${ }^{13}$ The latter country may be called the target. Of great interest to the analysis here is the typology of what is meant by a foreign power which can be a single state, a group of states, an international organization as well as a non-state actor. In the Greek case of the 1820s, a chronology of foreign influence may be ascertained as being initially a non-state actor who affected state-actors. The latter then made up the foreign powers in the above typology which intervened in the Ottoman Empire to support a specific ethnic and religious group in order to achieve its independence from the Ottoman yoke. Aidt et al., identify three foreign intervention strategiesonly the last of the three that are institutional interventions is of interest here. ${ }^{14}$ This strategy is further divided into two subcategories: regime interventions and conflict interventions. The latter are defined as those "...which cause, intensify, or end a violent conflict." As shown later, this was the case of the foreign interventions of the 1820 s by three foreign powers.

In the last few decades, the (economic) literature on wars has mushroomed. A big part of this relates to foreign interferences. Both theoretical and empirical studies have found that economic variables, such as low-income are related to revolutions and internal wars. Koubi and Bohmelt have concluded that one of the most common findings of the empirical literature is that higher incomes are correlated with lower probabilities of a revolution. ${ }^{15}$ In addition, Collier and Hoeffler have found that economic variables better explain internal wars than political and social variables. ${ }^{16}$ Brückner and Ciccone found that lower incomes increase the probability of an internal war, particularly when there are weak (or inexistent) democratic institutions. ${ }^{17} \mathrm{Lu}$ and Thies have proposed an interesting interpretation of the income and wealth variable. ${ }^{18}$ What is important is not if income (wealth) is low, but how this is perceived by people. If they think that are treated unfair, then they might joint a revolutionary coalition. ${ }^{19}$ A number of

13. Ibid, 431.

14. Ibid, 432.

15. V. Koubi and T. Bohmelt, "Grievances, Economic Wealth, and Civil Conflict," Journal of Peace Research 51, no. 1 (2014): 19-33.

16. P. Collier and A. Hoeffler, "Greed and Grievance in Civil War," Oxford Economic Papers 56, no. 4 (2004): 563-595; Collier and Hoeffler, "Civil War," in Handbook of Defense Economics 2 (ed.) T. Sandler and K. Hartley (Elsevier, 2007), 712-737.

17. M. Brückner and A. Ciccone, Growth, Democracy, and Civil War. CEPR Discussion Paper No. DP6568 (SSRN, 2007).

18. L. Lu and C. Thies, "Economic Grievance and the Severity of Civil War," Civil War 13, no. 3 (2011): 215-231.

19. The Ottoman Empire was not as bad as many Greeks think; many Greeks thrived under the Ottoman Empire. However, the Ottoman Empire failed miserably on its public 
other studies relate income differences to religion and ethnic differences as well, but with mixed results (see among many other studies Fearon, Fearon and Laitin, Reynal-Querol, Buhaug et al. $)^{20}$ It seems that one of the reasons of a revolution or a civil war is income (wealth) inequality, which, if it is related to religious and ethnic differences, raises the probability of the revolt. Was this the case in Greece in the 1820s? This question is addressed in the next section of the paper.

\section{The Greek Revolution of 1821 and the Two Civil Wars}

The1820s marks the beginning of the modern Greek state. The years which followed the formation of the new nation until the 1970s are characterized by revolutions, civil wars and foreign interferences. One may argue that all of these conflicts ceased when Greece decided to become a republic instead of a kingdom in 1975 with a referendum, but, most importantly, when it was accepted as a full member of the European Union the successor of the European Economic Community in 1981. Future historians will analyse this long period of 1821 to 1981 as being another homogeneous phase of the long history of the Greek race.

One may argue that the written history of Greece started with Homer's account of the Trojan War (around 1200 BCE); Herodotus' account of the GreekPersian Wars (early $5^{\text {th }}$ century BCE); Thucydides' unsurpassable historiography of the Peloponnesian War (late $5^{\text {th }}$ century BCE); Arrian's historical account of Alexander's conquer of the East $\left(4^{\text {th }}\right.$ century BCE, but written a few centuries later); and so many historians who followed them.

Unfortunately, many historians' works have been lost and only fragments have survived. In one of them, Hecataeus of Miletus (c. 550 BCE - c. 476 BCE) wrote that "Hecataeus of Miletus here declares: I write these, which I consider

relations with its own people. Even the richest of Greeks felt that they were unfairly treated by the Ottoman authorities, or even by a single individual Turk. This created an unnecessary rancor which resulted in almost all Greeks hating the Ottoman Empire and the Turks altogether, despite the many good examples of Turks who even sacrificed their lives to save Greek lives during the War of Independence. In that sense, I find Lu and Thies' (2011) interpretation applicable to the Greek revolt that demands a further analysis which goes beyond the scope of this study.

20. J. D. Fearon, "Why do Some Civil Wars Last so Much Longer than Others?" Journal of Peace Research 41, no. 3 (2004): 275-301; Fearon and D. D. Laitin, "Ethnicity, Insurgency, and Civil War," American Political Science Review 97, no. 1 (2003): 75-90; M. Reynal-Querol, "Ethnicity, Political Systems, and Civil Wars." Journal of Conflict Resolution 46, no. 1 (2002): 29-54; H. Buhaug, L.-E. Cederman and K. S. Gleditsch, "Square Pegs in Round Holes: Inequalities, Grievances, and Civil War," International Studies Quarterly 58, no. 2 (2014): 418-431. 
true; because the sayings of Greeks are, in my opinion, many and ridiculous." 21 With the exception of Thucydides' outstanding historical accounts, the rest of Greek historiography meets the criterion of "many and ridiculous."

The historiography about the 1820s was not an exception. The historical writings are many, but the quality of the analyses does not meet the basic criteria of scientific historical discourse. The problem is not so much the objectivity of accounting for the events of the 1820s, but the subjective incapability of those who wrote about the event-and they are so many - to provide a true analysis even if they wanted to. All of them are atheoretical and lack the internal coherence demanded by any historical analysis of such events, facts and data are mistreated. I have analyzed these issues elsewhere; see Papanikos.22

The historical sources ${ }^{23}$ can be divided into those which were written by eyewitnesses of the events and those whose authors did not experience the events, but wrote about them much later, based on facts and data provided by the eyewitnesses and by looking at official and other documents which had since become available. Furthermore, the written evidence provided by the eyewitnesses can be divided between those who attempted to provide an overall account of the events of the 1820s, and those who described specific events as personal memoirs and as part of their autobiography. In many cases these autobiographies were not written by them because they were illiterate, but by someone else which might have influenced how the events were portrayed. Most importantly, since these memoirs and autobiographies were written long after the events, the views might have served the needs of the period in which they were written. This is definitely the case of the civil wars since the political repercussions have a tendency to persist for decades. Finally, for many of them who today are considered the heroes of revolution, their posthumous fame was important and their writings quite possibly reflect this human ambition as well.

Two sources both written by foreigners who actually participated in the events like Thucydides, an Athenian general who fought in the Peloponnesian

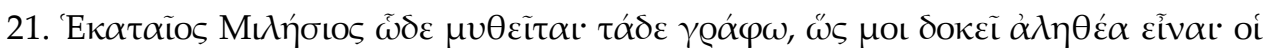

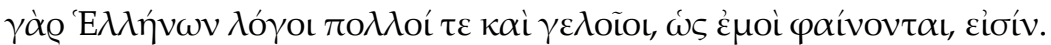

22. Papanikos, What is History? An Assessment of Carr's Monograph (Athens, Greece: ATINER, 2020); Papanikos, "The Use of History as a Tool of Policy-Making," Opening Speech at the $4^{\text {th }}$ International Conference on History: From Ancient to Modern. Athens, Greece, 28-31 December 2006 (National Archaeological Museum of Athens, 2006); Papanikos and N. C. J. Pappas, European History: Lessons for the 21st Century: Essays from the 3rd International Conference on European History (Athens, Greece: ATINER, 2006); Papanikos, "European History: Lessons for the 21 ${ }^{\text {st }}$ Century," in European History: Lessons for the 21st Century: Essays from the 3rd International Conference on European History (ed.) Papanikos and N. C. J. Pappas (Athens, Greece: ATINER, 2006), 3-8.

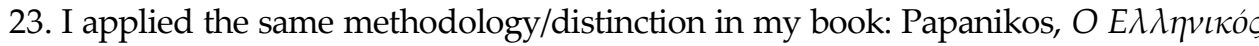

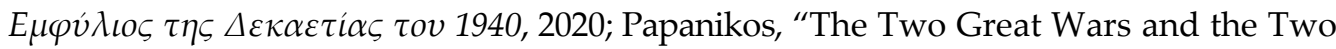
Great World Crises," Archives of Economic History Special Issue (2000): 99-106. 
War-are worth mentioning because they provide an overall account of the events of the 1820s even though their history cannot compare with Thucydides' history of the Peloponnesian War. Thomas Gordon (1788-1841) was a British army officer who played a role in the Greek War of Independence in the 1820s. He will be remembered for his history of the war which was published in 1832. Many have used his work as the main source of the Greek War of Independence. George Finlay (1799-1875) wrote a much better history of the Greek revolution (published in 1861), but even his history is based on Gordon's earlier work. ${ }^{24}$ Both are standard reference books of the Greek War of Independence and are used by many authors thereafter. I also use them as well in this study.

Apart from these sources, many other writings have appeared ever since the break of the revolution which aimed to explain why Greeks revolted against the Ottoman Empire in general, and during the 1820s in particular..$^{25}$ The demand to overthrow the Ottoman yoke was always there; ever since the collapse of the Byzantine Empire. But it was the Latins who first sacked Constantinople in 1204 during the Fourth Crusade which paved the way to the Ottoman occupation of Constantinople in $1453 .{ }^{26}$ Even though it goes beyond the scope of this paper, one may argue or hypothesize that the fall of Constantinople to the Ottomans was the rational choice made by Greek Orthodox leaders when faced with two choices: accept the head of the catholic church and Catholicism in general, or accept the Sultan as political leader but keep the Greek Orthodox faith. They chose the latter because they believed that the Ottoman occupation would be short-lived. On the other hand, succumbing to the Pope would be a permanent event. As turned out, the Ottoman occupation was temporary, but lasted more than 400 years. It still lasts even today if one considers that Constantinople is under the occupation of the successors of the Ottoman Empire. ${ }^{27}$ On the other hand, succumbing to

24. G. Finlay, History of the Greek Revolution (Edinburgh and London: William Blackwood and Sons, 1861).

25. Gordon (1832) in his preface mentions that forty books had already been published but only three or four could be considered accurate. Furthermore, as I have already pointed out, most, if not all, of these writings account for isolated war events. Gordon's own experience as a Greek army officer and his friendship with many people who were eyewitnessing the events were his sources.

26. D. Jacoby, "After the Fourth Crusade: The Latin Empire of Constantinople and the Frankish States," In The Cambridge History of the Byzantine Empire c.500-1492 (ed.) J. Shepard (Cambridge: Cambridge University Press, 2019), 759-778.

27. There is a dark side to the occupation issue of Constantinople which is not emphasized so much in the relevant political and historical literature. One could argue that Catholics (or the Pope) would never support the return of Constantinople to Greek Orthodox authorities because the polis is the holy city and the holy seat of the Ecumenical Patriarch of all Greek Orthodox Churches. Thus, if a Greek Orthodox prefers the Ottomans in order to avoid the dominance of Catholics, and a Catholic prefers the Ottomans in order to avoid the Greek Orthodox from getting more prestige and threaten the Vatican, then it is not surprising that Constantinople will remain occupied by a Muslim authority. Thus, 
Catholicism was not permanent either, as the protestant and other secessions from Catholicism have demonstrated.

Greeks wanted to get rid of the Ottoman Empire and had been preparing for it ever since the collapse of Constantinople in 1453. Many Greeks left Byzantine areas and migrated to Italy and other European countries, bringing with them their superior knowledge; particularly of ancient Greek grammar. As a coincidence, there was a great demand in the host countries for Ancient Greek language. Some have argued that the collapse of Byzantium spearheaded the Renaissance of Europe, but this is an egg-chicken argument, or, in economic jargon, a causality effect. ${ }^{28}$ Did the migration cause the renaissance in Europe or was the renaissance in Europe which created a demand for educated Greeks resulting to their emigration? Or, is it a pseudo-relation and there is another causal variable (reason) which forced both variables (migration and renaissance) to move together? These very important questions go beyond the scope of this paper and beyond the ability of this paper's author to address them.

Why would Greeks want to revolt against the Ottoman Empire? The theoretical answer to this question is given by Roemer as presented in the previous section of the paper. ${ }^{29}$ According to his theory, the purpose of a revolution is income distribution. Greeks and Ottomans were competing for the same scarce resources by forming coalitions and applying force to achieve their objectives. Of course, a revolution brings benefits if victorious, and entails high costs if fails. The last might include loss of life and definitely a worsening of the income and wealth situation relative to the pre-revolution stage ${ }^{30}$ From the siege and the fall of

the dark sides of this story took place in 1204 when Constantinople was sacked by Latins under the auspices of the Pope, then the occupation of Constantinople by Muslims in 1453 followed. These are well-known historical facts. An unknown fact which belongs to the dark side of the issue is the liberation of Constantinople by Christian forces in 1918. A century ago, the joint-military forces of France, England and Italy occupied Constantinople for five years from 3 November 1918 to 4 October 1923. If they wanted, they could have made it a Christian city state, and Hagia Sophia its Christian cathedral. In the 1920s, half of Constantinople's population was non-Muslim with many westerners living in the city. Instead, the Christians' non-Orthodox powers decided to peacefully return it to a Muslim authority. Now some of them lament crocodile tears that Hagia Sophia became a mosque.

28. K. M. Setton, "The Byzantine Background to the Italian Renaissance," Proceedings of the American Philosophical Society 100, no. 1 (1956): 1-76; J. Harris, Greek Emigres in the West, 1400-1520 (Camberley: Porphyrogenitus, 1995).

29. Roemer, "Rationalizing Revolutionary Ideology," 1985.

30. Worst of all, wars bring pandemics as it did in ancient Peloponnesian War so eloquently described by Thucydides; Papanikos "Thucydides and the Synchronous Pandemic," Athens Journal of History 7, no. 1 (2021): 71-94. The effect of the pandemic in Ancient Athens resulted to huge losses of life which included Pericles' life. Today COVID19 apart from the impact on lives and wellbeing it affects the economy primary through tourism; see Papanikos, "The Impact of the COVID-19 Pandemic on Greek Tourism," Athens Journal of Tourism 7, no. 2 (2020): 87-100. 
Constantinople in 1453, Greeks were defending whatever remained of the Byzantine Empire, but were outnumbered by the attacking Ottomans. Thus, it was imperative to form a coalition with other forces to enable them to cope with the Ottomans. This situation remained unchanged throughout this long period, 1453-1821. In all of the occasions that the Greeks revolted against the Ottomans, this was in collaboration with some other foreign powers. Some examples, without any further analysis, are the following: ${ }^{31}$

1. Ottoman-Venetian War (1463-1479).

2. Around 1571 (Battle of Lepanto), a number of revolts occurred such as in Epirus, Phocis and the Peloponnese.

3. Short uprisings led by bishop Dionysius the Philosopher in Thessaly (1600) and Epirus (1611).

4. The Cretan War (1645-1669): Greeks assisted Francesco Morosini and the Venetians in the Peloponnese and the Ionian Sea.

5. The Orlov Revolt during one of many Russian-Turkish wars (1768-1774).

6. In 1778-1790, a Greek fleet of seventy vessels led by Lambros Katsonis engaged in a number of naval battles with the Turkish fleet.

The above shows that there was only one reason which explains why Greeks revolted against the Turks and the Ottoman Empire: they wanted their freedom. Ever since the collapse of the Byzantine Empire in 1453 which followed the occupation of Constantinople by Franks in 1204, Greeks never stopped the fight for their independence. Unfortunately, all of these revolts failed. However, what did not fail was the permanent uprising of small groups of Greeks called armatoloi and klephtes who would rob and punish Turks and any other who happened to be at their reach, including visitors to Greece who went there to admire the remnants of her past glory. Of course, Thucydides had warned all future generations that these Greek "pirates" existed in the mainland and in the sea, at least since the second millennium BCE. In many areas of Greece, these armed gangs became the de facto rulers; no Ottoman would dare to cross their territories. They would collect taxes from the local population in collaboration with Ottoman authorities. The distinction between armatoloi and klephtes was that the former groups' chieftains were appointed by Ottomans to collect local taxes while the latter were doing sort of the same thing but without the permission of the Ottoman authority. Of course, in the eyes of the people, both were the same, and in many occasions, the two groups were interconnected. These small groups of armed gangs were the ones who rebelled against the

31. Many writings account for the wars of this long period of more than four centuries. For example, Davies and Davis (2007) look at wars between Venice and the Ottoman Empire. Venice's involvement in the area started much earlier with the conquer and plunder of Constantinople in 1204. 
Ottoman Empire in 1821. Their motive was mainly economic; they wanted to gain from the spoils of a collapsing Ottoman Empire. However, this time was different. The probability of being successful in getting rid of the Ottoman Empire altogether was higher.

Two events which took place in the $18^{\text {th }}$ century increased the probability of a successful Greek revolution. Firstly, throughout the $18^{\text {th }}$ and the early $19^{\text {th }}$ centuries, the Ottoman Empire was collapsing and suffering from major internal (civil) wars. It was forced to sign two peace treaties of Küçük Kaynarca in 1774 and Jassy in 1792, as a result of two Russian-Turkish Wars. The most important concession made by Ottomans was Article XI of the first treaty which allowed "... free and unimpeded navigation for merchant ships of both countries. Subjects of both Empires may also trade on land." This was a great opportunity for Greeks to develop their merchant trade under the protection of the Russian Empire. And so, they did. Their ships were using the Russian flag.

The second event was the outbreak of the French Revolution. The effect was positive but for different reasons from what many "ridiculous" Greek historiansand they are "many" - are claiming. ${ }^{32}$ They do see the true correlation (causality) between the French Revolution and the Greek War of Independence, but they think that it was the ideas of the enlightenment and the emergence of French Revolution which "caused" the Greek revolution. This is a pseudo-correlation of the two events. The real causality was mentioned by Gordon as early as in 1832 . The war had paralyzed the French commercial fleet and there was a great demand for wheat which was satisfied by the Greek commercial fleet. The result was an unprecedented increase in the Greek ownership of ships. Gordon mentioned that in 1816 this fleet accounted for more than 600 vessels with 17,000 people working on them, and carrying more than 6,000 canons. Gordon wrote: ${ }^{33}$

The thirty years that elapsed from 1790 to 1820, made, in the ideas and prospects of the Greeks, a wonderful alteration, proceeding chiefly from two causes; the growing influence acquired by Russia in Eastern affairs after the peace of Yassy, and the consequences of the French revolution. The first afforded them hopes of future liberation, as well as ready means of exchanging obedience to Ottoman authority, individually, for the protection of the court of St. Petersburg, through the medium of the Russian embassy at Constantinople. The second, by creating a demand for corn in the ports of the West, sharpened their instinctive love of commerce and navigation, and, for a paltry coasting traffic in small barks, substituted strong and lofty vessels, distant voyages, and extensive speculations. By unlocking the straits between the

32. This of course is based on claims made by Finlay $(1861$, p. 20) who wrote that, "At the commencement of this century the effects of the French Revolution were strongly felt in Greece." I think Gordon's economic interpretation is much better and more persuasive. The French Revolution did have an effect, but it was an economic effect which enriched many Greek merchants and developed a considerable merchant shipping fleet.

33. Gordon, The History of Greek Revolution, 1832, 35-36. 
Euxine and the Mediterranean, the Empress Catharine had procured an outlet for the harvests of Poland and southern Russia. The new town of Odessa, built on a Tartarian steppe, attracted a multitude of Greeks, all occupied in commercial pursuits. War had paralyzed the merchant marine of France; while that of Austria, now so flourishing, did not as yet exist. Thus the trade of the Black Sea fell, without competition, into the hands of some islanders of the Egean. The impulse once given was followed up with singular alacrity: at Constantinople, Smyrna, Salonika, and every great city of the Turkish empire -- at Odessa, Trieste, Leghorn, and all the principal ports of Europe, were established opulent Greek houses, whose rising prosperity casting into shade that of the foreign Levant merchants, excited too commonly in the breasts of the latter a rancorous feeling of hostility, which has been its own punishment. In 1816, the number of vessels belonging to the Christian subjects of the Porte, and fitted out from the havens and islands of Thrace, Macedonia, and Greece, (many of them, however, carrying the Russian flag,) amounted to upwards of 600, employing 17,000 seamen, and armed with 6000 pieces of cannon. Nor was it on the coasts alone that trade gained ground, the movement communicated itself to the secluded valleys of Pindus, Ossa, and Cyllene; and the woolen manufactures of Thessaly and Epirus, the exportation of oil from Crete, of currants, silk, and other commodities from Peloponnesus, brought in considerable sums, and vivified countries hitherto poor and neglected. It is universally admitted, that commerce essentially contributes to the progress of knowledge and refinement, and that the Greeks are as anxious as they are apt to learn.

The above analysis can be depicted in a schematic form as Gordon's explanation of not only the eruption of the Greek revolt against the Ottoman Empire, but the reasons of its success. However, the success of creating a Greek state was achieved only after the foreign intervention. This is explained by another model to be developed in the next section.

Figure 1 depicts what can be called Gordon's model of the Greek revolution. A few comments are in order here. Two events of the $18^{\text {th }}$ century-already mentioned above-gave rise to an unprecedented accumulation of wealth in the hands of Greek merchants who were located all over the then-known world, inside and outside the Ottoman Empire. Many Greeks used the surplus of this unprecedented accumulation of wealth to promote education inside and outside the Ottoman Empire and prepare a War of Independence if conditions were favorable; this provided the human and physical capital of the desired revolution. In 1815 a secret society was formed by three merchants that aimed at liberating Greece from the Ottoman yoke. Even though it is questionable how this helped the events of the revolution, there is no question that it helped mobilize many Greeks around the world. For example, investments in education were huge. New schools were established inside and outside of Greece. Books were published of both ancient Greek literature and of current concerns. A good example of this is the work of Adamantios Korais. Greeks, along with other educated Europeans, discovered the glorious past of Greece in all areas of epistemes; natural and metaphysical. Thus, educated Greeks (those who read Pericles' funeral oration) 
could not stand the Ottoman yoke, or to that extent, any yoke. But, most importantly, they understood that in an independent Greek state their economic benefits would be much higher. Thus, a revolution was not based so much on a romantic ideal of reviving the past by on hard economic needs to make more profits and accumulate more wealth. The substitution of the collapsing Ottoman Empire with a new independent Greek state could provide the necessary stability and freedom to profit from the new world's economic opportunities. If Greek merchants thrive under the Ottoman Empire, imagine how much better-off they would be in a freer business environment.

Figure 1. Gordon's Model of the Eruption of the Greek War of Independence

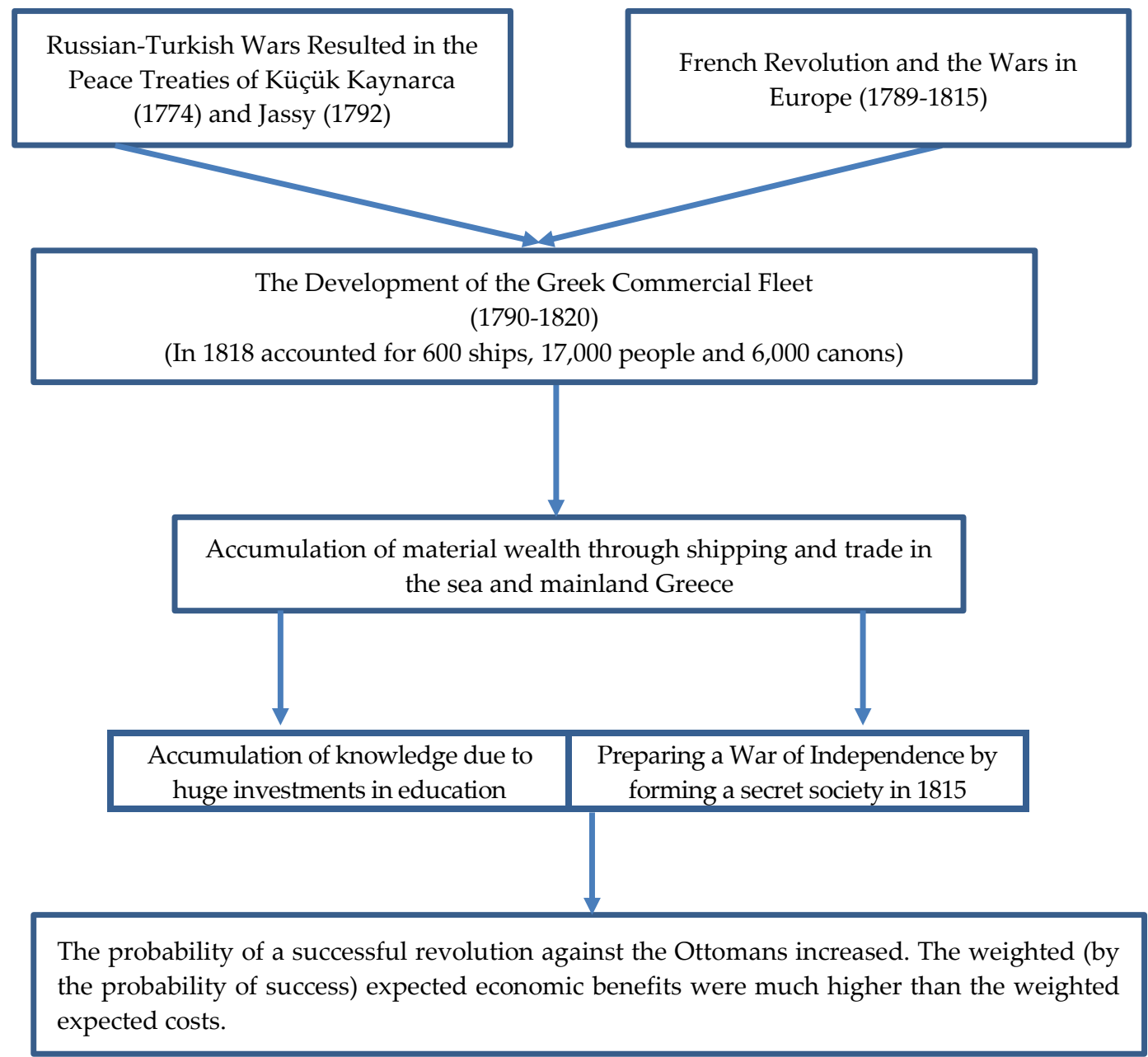

The above description explains why the rich Greeks of diaspora supported the revolution. What about the armatoloi and klephtes of mainland Greece? What was at stake for them? Many were very reluctant to participate in yet another revolution because the disaster of the Orlov was still in their memory. In addition, they did not consider the Ottoman yoke so bad. In certain areas of Greece, there was more religious and economic freedom than in any other place in Europe. 
How would one compare the area of Akarnania, for example, with the area of Scotland in 1820? Armstrong describes the military events and the execution of the Scottish insurrectionists accused for treason in $1820 .{ }^{34}$ From a rational point of view, an individual who would be presented with two choices in 1820, Akarnania under Ottoman Empire or Scotland under the British Empire, I am sure they would have selected Akarnania as being safer and freer.

Gordon's model emphasizes the economic aspects of the War of Independence. The improvement in income and wealth of Greeks became a cause of the revolution because they were expecting more material benefits. In the 1820s, Greeks had the material means to support the outbreak of the revolution, but as is shown, the material means were not sufficient and the Greek rebels were recognized as fighting for the creation of a state by Britain which qualified them to draw two loans in 1824 and 1825. Yes, the loaners were British. ${ }^{35}$

In the beginning, the revolution was very successful. Small and large cities were sieged and eventually were conquered by Greek rebels. Many Ottomans were massacred and their wealth became prey to the Greek bandits. The most important case was the massacre of Turks after Greeks conquered the city of Tripoli in the middle of the Peloponnesus. ${ }^{36}$ The fall of Tripoli was followed by the worst looting in the history of the Greek War of Independence. A disgusted Thomas Gordon would quit Greece after these barbaric actions against innocent people, women and children. ${ }^{37}$ The War of Independence became a war of income and wealth distribution between Ottomans and Greeks. However, this income

34. M. Armstrong, The Fight for Scottish Democracy: Rebellion and Reform in 1820 (London: Pluto Press, 2020).

35. Reinhart and Trebesch (2015) examine the long history of Greek debt concluding that Greece was "addicted" to foreign borrowing. There many such ahistorical explanations that sometimes go beyond the limits of academic decency.

36. Another important issue which is not discussed here is whether Greeks would have preferred an Ottoman rule, as opposed to say, a Venetian rule because of lower taxes and a more tolerant rule compared to any western catholic ruler (Dakin 1973). This is an important issue and might explain why Greeks living abroad, including in the Ottoman Empire, preferred, after the formation of the Greek independent state in 1832, to stay abroad and not come to their liberated homeland. Patriotism notwithstanding, I think economics might very well explain such decisions.

37. These are described in Phillips (1897) and more recently by St Clair (2008) as well as in many others including chieftain Kolokotronis' memoirs. There are always many excuses of such barbaric atrocities and the Great Thucydides has warned us. What separates barbarians from civilized ones is when they face such challenges, they punish those who were responsible for a criminal action and not massacre indiscriminately people who by definition were innocent. These Greek gangs who entered Tripoli were barbarians. And once a barbarian, always a barbarian. If the excuse was that they were of different ethnicity and religion who oppressed them for four hundred years, they did exactly the same thing to their own people during the same year as part of the civil wars which followed the first successes of the War of Independence. 
and wealth distribution had a second phase. The first phase was to maximize the extraction of wealth from Ottomans and other non-Greek ethnicities. The second phase was the most difficult one because there was no efficient and effective mechanism to distribute the spoils between the Greeks themselves. Eventually this mechanism was found and it resulted in the two civil wars. The main reason of the two civil wars was the distribution of wealth which was extracted from the Turks and the other subjects of the Ottoman Empire, e.g., Jews.

As already mentioned, Greeks would never be able to achieve their national cause without the direct (military) and indirect (economic and diplomatic) foreign interference. ${ }^{38} \mathrm{~A}$ good discussion of the world situation at the time is provided by Stivachtis (2018) and I will not elaborate here. The next section will emphasize the economic aspects of the foreign interference.

\section{The Foreign Interference and the Establishment of a Greek State}

Figure 2 presents a model of the foreign interference in the 1820s. The most important box of this model is the world political developments or the European international society. ${ }^{39}$ The European (world) political environment was not conducive to ethnic revolutions. The Congress of Vienna of 1814 (November)1815 (June), chaired by Austrian Klemens von Metternich, among many other things, was against any revolutions in Europe, or to that extent, anywhere in the world. Force could be used to suppress them and so they did: in 1821 Austria send their army to suppress a revolt in Italy; in 1823 France intervened in Spain; and in 1826 Britain intervened in Portugal. However, there was a loophole which could be used by any of the European powers to support the Greek revolution because the Ottoman Empire was not clear whether it was part of the agreement or not. In addition, the Ottomans were Muslims and the Greeks, Christians. This also created a crack in the agreement.

At the same time and as a coincidence, the ideology of romanticism swept Europe which revived the interest in classical studies, Greek being the most important of them. I think if there is any ideological context in the Greek revolution, this can be found in the movement of romanticism. However, this

38. I have examined growth, trade and military skirmishes in the Mediterranean in Papanikos, "Military Spending, International Trade and Economic Growth in the Mediterranean Basin," Athens Journal of Mediterranean Studies 1, no. 2 (2015): 187-194. However, today this relates very much to energy which as an issue has been examined in Papanikos, "Energy Security, the European Energy Union and the Mediterranean Countries," in the Roundtable Discussion on Energy Security and Policy in the South European Peninsula and the Mediterranean Basin (Athens, Greece: ATINER, Monday 30 March 2015).

39. Y. A. Stivachtis, “'International Society' Versus 'World Society': Europe and the Greek War of Independence," International Politics 55, no. 1 (2018): 108-124. 
would never be sufficient by itself to begin a War of Independence. However, once the Greeks revolted against the Ottomans, the movement of Philhellenism grew stronger and stronger which was fueled by the news of the Ottoman atrocities against the "heroic" Greeks who were fighting to restore the glory of the past. A whole literature has developed to explain all these, including who were these Greek rebels. Were they really Greeks? Yes, the Philhellenist would say, because they spoke Greek. This of course was even further documented by the Greek intelligentsia of diaspora. Adamantios Korais was one of them who, by the way, was not fond of the timing of the Greek revolution, but once the revolution started, he used of all his power to support it, including his friendship with the USA President.

Figure 2 shows the complexity of the interactions of the various forces which led to the foreign interference. A few comments will help to explain the figure. First, Ottomans failed badly in building international coalitions. They needed a public relations manager but their structure was such that they did not understand that the world was changing, and in this new world they would never be a leading force unless they were westernized. This failure in understanding what was going on in the world led to the collapse of the Ottoman Empire one century later, and the eventual establishment of modern Turkey in 1923 by Kemal Ataturk who changed many things so that the Turks would become a European-civilized country. The Ottoman atrocities during the Greek War of Independence had two effects. First, many people of influence were mobilized to help the Greek cause, and by their artistic work and writings they were able to influence the greater public opinion to act by collecting money and/or travel to Greece to fight against the Ottomans to liberate not only Greece, but the civilization itself from barbarism which was represented by Ottomans, by the easterners, by the Muslims. The public opinion became favorable and where this counted, especially in France and Britain, governments were under pressure to act in favor of Greece. Even in countries where public opinion did not count at all, such as in Russia and Austria, the Ottoman atrocities, such as the hanging of the Greek Ecumenical Patriarch of Constantinople and the throwing of his body into the sea by a gang of people, were considered as a great insult to Russia. Austria's support for the Ottomans was not taken seriously by any other European power anymore. 
Figure 2. A Model of Foreign Interference in the Greek War of Independence

Development of romanticism and classicism gave rise to Philhellenism in Europe and in USA during the $18^{\text {th }}$ and $19^{\text {th }}$ centuries

European public opinion became favorable to the Greek cause for independence from the Ottoman Rule

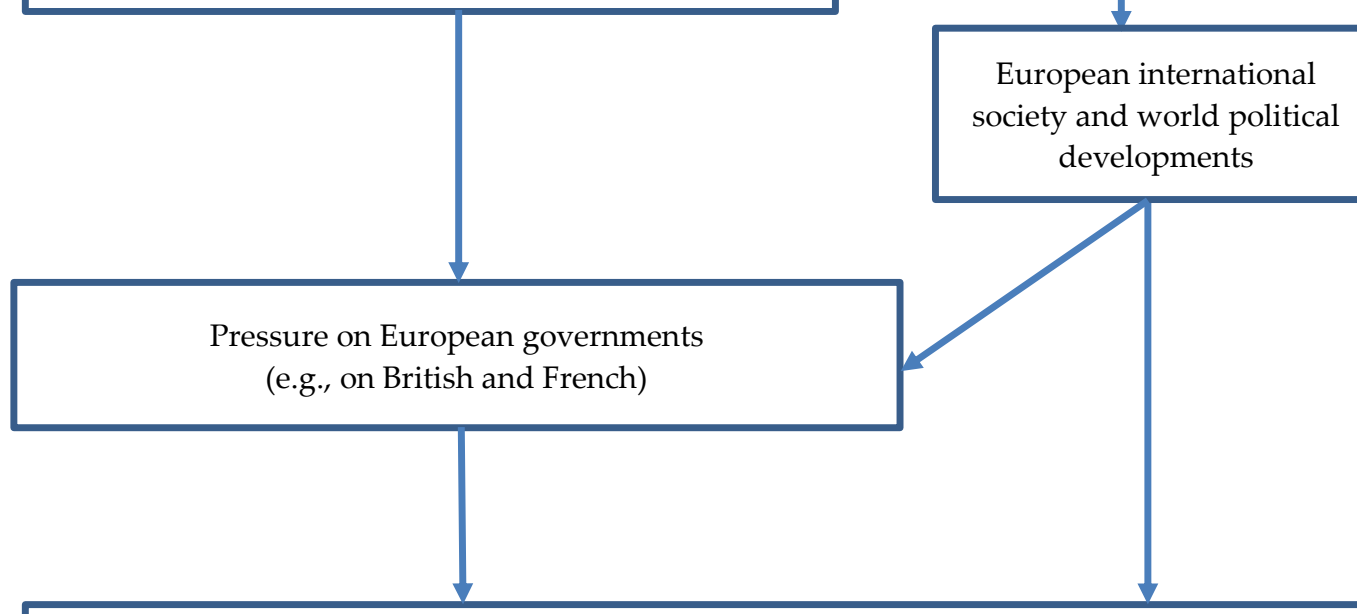

Foreign intervention in the Greek War of Independence (Britain, France, Russia)

Official Establishment of a Greek State in 1832

For these and perhaps for many other reasons, the British government thought that they could do "business" with a new Greek state. The recent example of the Mexican War of Independence from Spain (1810-1821) taught the British government some important lessons which could be applied to the Greek case. As a coincidence, the Mexican and the Greek wars each lasted 11 years. The British started negotiation with Mexico right after their establishment as an independent state and provided them with a loan in 1822. ${ }^{40}$ Similarly, the British started negotiating with the Greek rebels which ended with the provision of two

40. C. A. True, "British Loans to the Mexican Government 1822-1832," The Southwestern Social Science Quarterly 17, no. 4 (1937): 353-362. 
loans in 1824 and $1825 .{ }^{41}$ The die was cast. Greece, as Adamantios Korais had so wisely prognosed, became part of the British Empire and her destiny will follow the British destiny until 1947 when the USA replaced her. This was the best option for Greeks at the time and it was not bad at all. They had the great support of the people (public opinion) of British and USA. Very difficult for their governments would ago against their people' will. The fact that Greeks were unable to take full advantage of this should not be blamed on foreign governments but on Greek governments themselves.

In 1825 Britain revealed her preference for Greece by committing itself with two loans. Of course, the loans were owned by British people and not just by the government, but the British government would always support her individual subject even with the means of gunboat diplomacy as Greeks found out very quickly after 1832 .

The Ottomans did not make a note of that and still they would argue that the Greek War of Independence was an internal affair and the other countries should not interfere. It was a matter of time, Ottomans argued, to crash this rebellion as they had done many times in the past. They could do it themselves, and they were almost there by 1825 . From a military point of view, Greeks had lost the war by the mid-1820s but Britain along with France and Russia had other ideas. They told the Sultan their ideas and he did not like them. Paraphrasing the famous Thucydides trap argument, I might say that when a civil wish by a superpower (e.g., Britain) is ignored by a declining great power (e.g., Ottoman Empire), then a war is inevitable. In 1827 and 1828 the joint forces of Britain, France and Russia gave a hard lesson to Sultan on gunboat diplomacy. Some naively argue that the naval battle of Navarino in 1827 started as a mistake. Some others argued that it was a mistake. When so many battle ships are concentrated in one small area, they are there for a rational purpose: to support the economic interests of the participating countries. Similarly, some historians argue that the naval battle of Salamina started as a mistake. Thus, the three powers were at Navarino with their naval battle ships and regular army (14,000 French soldiers were stationed in Peloponnesus) to enforce what they had agreed upon: the creation of an independent Greek state. They were willing to avoid the battle if the Ottomans retreated, but they did not and the choice of a battle became inevitable. The outcome was the result of rational choices made by both opposite forces. Rationality implies that all adults seated on the same table negotiate, and this is exactly what the Sultan did. This time was obvious who was at the head of the table. The first meeting took place in London (at the winners' table) and the second in Constantinople (at the losers' table). The London Conference and the Treaty of Constantinople were convened in 1832 and the result was a Greek state which was definitely independent from the Ottoman yoke. A new chapter in the

41. N. Apostolidis and C. Velentzas, Greece's Loans from the United Kingdom (18241825): Myths and Truths (Society for Hellenism and Philhellenism, 2020). 
Greek history had begun, which can be titled the British dominance in internal and external Greek affairs. This new exciting chapter is not examined in this paper. It is left for future research.

\section{Conclusion}

The 1820s is an important decade in the modern Greek history. In a way it looks like the 1940s. In both decades Greece experiences a War of Independence (liberation), two civil wars and a direct and indirect foreign intervention. Once again, Greek history repeated itself and always as a tragedy.

Thucydides wrote his history to teach all future generations how to avoid making the same mistakes over and over again, because, as he claimed, it is in human nature to repeat the same faults. Thus, in these conclusions it is useless to draw any lessons for the future generations of the human race.

The only humble purpose of this paper was to illustrate the economic dimensions of the three events that took place in the 1820s in Greece. The War of Independence can be interpreted as an economic war between Greeks and Ottomans. Similarly, the two civil wars were the result of distributing the spoils of the war against the Ottomans between various Greek gangs. Finally, foreign interference (from 1827 onwards) protected the economic interests of Britain which had committed herself as early as 1824 .

This paper does not argue that other reasons, apart from economic, did not play a role. On the contrary, they played a significant role, particularly in determining the results of the events of the 1820s which were the creation of a Greek state, independent from the Ottoman Empire, but attached to the British Empire. An economic cost-benefit analysis would show that the net present value of the latter was much higher than in the first option. In 1947 the USA option gave higher net present value, and by 1981 the European Union was a much better (investment) alternative and still is today, 200 years after the Greek revolution. Until the next alternative comes forward, all these choices make perfect rational, economic sense and can be explained by economic theory alone.

\section{Bibliography}

Acemoglu, D. and A. Wolitzky. "Cycles of Conflict: An Economic model." American Economic Review 104, no. 4 (2014): 1350-1367.

Aidt, T. S., F. Albornoz and E. Hauk. "Foreign Influence and Domestic Policy." Journal of Economic Literature 59, no. 2 (2021): 426-487.

Apostolidis, N. and C. Velentzas. Greece's Loans from the United Kingdom (1824-1825): Myths and Truths. Society for Hellenism and Philhellenism, 2020.

Armstrong, M. The Fight for Scottish Democracy: Rebellion and Reform in 1820. London: Pluto Press, 2020. 
Brückner, M. and A. Ciccone. Growth, Democracy, and Civil War. CEPR Discussion Paper No. DP6568. SSRN, 2007.

Buhaug, H., L.-E. Cederman and K. S. Gleditsch. "Square Pegs in Round Holes: Inequalities, Grievances, and Civil War." International Studies Quarterly 58, no. 2 (2014): 418-431.

Collier, P. and A. Hoeffler. "Greed and Grievance in Civil War." Oxford Economic Papers 56, no. 4 (2004): 563-595.

. "Civil War." In Handbook of Defense Economics 2, edited by T. Sandler and K. Hartley, 712-737. Elsevier, 2007.

Dakin, D. The Greek Struggle for Independence, 1821-1833. Berkley: University of California Press, 1973.

Davies, S. and J. L. Davis. "Greeks, Venice, and the Ottoman Empire." In Hesperia Supplements, volume 40: Between Venice and Istanbul: Colonial Landscapes in Early Modern, 25-31. Athens: The American School of Classical Studies at Athens, 2007.

Eckstein, H. "On the Etiology of Internal Wars." History and Theory 4, no. 2 (1965): 13311363.

Esteban, J. and R. Debraj. "Linking Conflict to Inequality and Polarization." American Economic Review 101, no. 4 (2011): 1345-1374.

Esteban, J. and D. Ray. "Conflict and Distribution." Journal of Economic Theory 87, no. 2 (1999): 379-415.

Esteban, J., L. Mayoral and D. Ray. "Ethnicity and Conflict: An Empirical Study." American Economic Review 102, no. 4 (2012): 1310-1342.

Fearon, J. D. "Why do Some Civil Wars Last so Much Longer than Others?" Journal of Peace Research 41, no. 3 (2004): 275-301.

Fearon, J. D. and D. D. Laitin. "Ethnicity, Insurgency, and Civil War." American Political Science Review 97, no. 1 (2003): 75-90.

Finlay, G. History of the Greek Revolution. Edinburgh and London: William Blackwood and Sons, 1861.

Gordon, T. The History of Greek Revolution. Edinburgh and London: William Blackwood and Sons, 1832.

Grossman, H. I. "A General Equilibrium Model of Insurrections." The American Economic Review 81, no. 4 (1991): 912-921.

. “Kleptocracy and Revolutions." Oxford Economic Papers 51, no. 2 (1999): 267-283.

Harris, J. Greek Emigres in the West, 1400-1520. Camberley: Porphyrogenitus, 1995.

Jacoby, D. "After the Fourth Crusade: The Latin Empire of Constantinople and the Frankish States." In The Cambridge History of the Byzantine Empire c.500-1492, edited by J. Shepard, 759-778. Cambridge: Cambridge University Press, 2019.

Koubi, V. and T. Bohmelt. "Grievances, Economic Wealth, and Civil Conflict." Journal of Peace Research 51, no. 1 (2014): 19-33.

Lu, L. and C. Thies. "Economic Grievance and the Severity of Civil War." Civil War 13, no. 3 (2011): 215-231.

Papanikos, G. T. "The Two Great Wars and the Two Great World Crises." Archives of Economic History Special Issue (2000): 99-106. Available at: https://bit.ly/31QIejB.

. "The Use of History as a Tool of Policy-Making." Opening Speech at the $4^{\text {th }}$ International Conference on History: From Ancient to Modern. Athens, Greece, 28-31 December 2006. National Archaeological Museum of Athens, 2006. Available at: https://www.atiner.gr/gtp/Papanikos(2006)-History.pdf. 
. "European History: Lessons for the 21 ${ }^{\text {st }}$ Century." In European History: Lessons for the 21st Century: Essays from the 3rd International Conference on European History, edited by G. T. Papanikos and N. C. J. Pappas, 3-8. Athens, Greece: ATINER, 2006.

. "Military Spending, International Trade and Economic Growth in the Mediterranean Basin." Athens Journal of Mediterranean Studies 1, no. 2 (2015): 187-194. Available at: http://www.athensjournals.gr/mediterranean/2015-1-2-4-Papanikos.pdf).

. "Energy Security, the European Energy Union and the Mediterranean Countries." In the Roundtable Discussion on Energy Security and Policy in the South European Peninsula and the Mediterranean Basin. Athens, Greece: ATINER, Monday 30 March 2015. Available at: http://www.atiner.gr/gtp/Papanikos\%20(2015)-Energy\%20Security.pdf. . What is History? An Assessment of Carr's Monograph. Athens, Greece: ATINER, 2020. Available at: https://www.ati ner.gr/gtp/Papanikos(2020)-Carr.pdf.

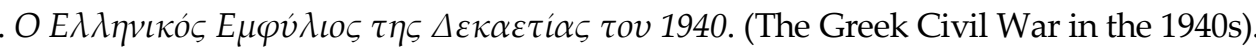
Athens, Greece: ATINER, 2020. Available at: https://www.atiner.gr/gtp/Papanikos (2020)-Civil-War.pdf.

. "The Impact of the COVID-19 Pandemic on Greek Tourism." Athens Journal of Tourism 7, no. 2 (2020): 87-100. Available at: https://www.athensjournals.gr/tourism/ 2020-7-2-2-Papanikos.pdf.

. "Thucydides and the Synchronous Pandemic." Athens Journal of History 7, no. 1 (2021): 71-94. Available at: https:/www.athensjournals.gr/history/2021-7-1-4-Papani kos.pdf.

Papanikos, G. T. and N. C. J. Pappas. European History: Lessons for the 21st Century: Essays from the 3rd International Conference on European History. Athens, Greece: ATINER, 2006.

Phillips, W. A. The War of Greek Independence 1821 to 1823. New York: Charles Scribner's Sons, 1897.

Reinhart, C. M. and C. Trebesch. The Pitfalls of External Dependence: Greece, 1829-2015. Brookings Papers on Economic Activity, 2015.

Reynal-Querol, M. "Ethnicity, Political Systems, and Civil Wars." Journal of Conflict Resolution 46, no. 1 (2002): 29-54.

Roemer, J. E. “Rationalizing Revolutionary Ideology.” Econometrica 53, no. 1 (1985): 85-108.

Setton, K. M. "The Byzantine Background to the Italian Renaissance." Proceedings of the American Philosophical Society 100, no. 1 (1956): 1-76.

St Clair, W. That Greece Might Still be Free: The Philhellenes in the War of Independence. 2nd Edition. Cambridge: Open Book Publishers, 2008.

Stivachtis, Y. A. “'International Society' Versus 'World Society': Europe and the Greek War of Independence." International Politics 55, no. 1 (2018): 108-124.

True, C. A. "British Loans to the Mexican Government 1822-1832." The Southwestern Social Science Quarterly 17, no. 4 (1937): 353-362. 